\title{
IAMJ
}

INTERNATIONAL

AYURVEDIC

MEDICAL JOURNAL

\section{A STANDARD COMPARATIVE CLINICAL STUDY ON PANDUROGA W.S.R TO IRON DEFICIENCY ANAEMIA WITH SAMMOHA LOHA OVER FERROUS SULPHATE}

\author{
Rajeshwari M S 1 , R V Shettar ${ }^{2}$ \\ ${ }^{1}$ Final Year PG Scholar, Dept. of Kayachikitsa \\ ${ }^{2}$ M.D (Ayu), Professor, Dept of Kayachikitsa \\ Shri D.G.M. Ayurvedic Medical College and Hospital Postgraduate Studies and Research Centre, Gadag, \\ Karnataka - 582103
}

Corresponding Author: msrajeshwari312@gmail.com

https://doi.org/10.46607/iamj06p5062021

(Published online: September 2021)

Open Access

(C) International Ayurvedic Medical Journal, India 2021

Article Received: 29/08/2021 - Peer Reviewed: 12/09/2021 - Accepted for Publication: 15/09/2021

Check for updates

\begin{abstract}
Context: Anemia is the most common and intractable nutritional problem in the world today. Anaemia due to iron deficiency is the most prevalent type of Anemia. As the name denotes the main feature of Panduroga (Anemia) is Pandutva (pallor). Panduroga as mentioned in classics is a Pitta PradanaVyadhi. The side effects of oral allopathic drugs are very common, therefore a study on Ayurvedic formulation SammohaLoha was chosen in the study. Aim: Evaluation of the efficacy of SammohaLoha over Ferrous Sulphate in Panduroga. Materials and Methods: Randomized, single-blind standard comparative clinical study. The study was conducted on 40 patients, and they were divided into 2 groups each with 20. One group was treated with trail drug SammohaLoha and the other group with standard drug Ferrous Sulphate. Clinical parameters were documented before and after treatment. Results: After statistically assessment of subjective and objective parameters results were drawn.
\end{abstract}

Keywords: Panduroga, Iron Deficiency Anaemia, SammohaLoha, Ferrous Sulphate 


\section{INTRODUCTION}

The world's population is increasing at a rapid rate, due to which most of the people are living in unhygienic, under-nourishing conditions. Adaption of people towards western culture like fast foods intake like pizza, chips, burgers, carbonated drinks etc are considered as low nutrient foods and as well they impair the digestion and affect the absorption of various nutrients including iron and also varies stress and strain factors affects the health. This disease was chosen for the study due to its high incidence.

Globally $50 \%$ of anaemia is attributable to iron deficiency $^{1}$. Generally, symptoms like fatigue, headache, giddiness, breathlessness and palpitations are seen in anaemia $^{2}$. Oral iron salts are the most readily available way of replacing iron, Ferrous Sulphate is the most effective and economical oral preparation. But about $10-20 \%$ of patients will develop gastrointestinal side effects related to Ferrous Sulphate these range from nausea, epigastric discomfort, vomiting, constipation and diarrhoea ${ }^{3}$. Hence an attempt was made to compare the effect of SammohaLoha over Ferrous Sulphate.

\section{Aim and Objectives:}

- To evaluate the effect of SammohaLoha in Panduroga.

- To compare the efficacy of SammohaLoha over Ferrous Sulphate in Panduroga.

Materials and Methods:

Study Design: Randomized control single-blind comparative clinical study. It was conducted on subjects suffering from IDA. A computer-based randomized technique was adopted ${ }^{4}$.

Sample Size and Grouping: A minimum of 40 patients suffering from Panduroga were selected and made into two groups randomly, Group A-20 patients and Group B-20 patients.
Selection of Cases: Patients suffering from the Signs and Symptoms of Panduroga (IDA) were selected from O.P.D. and I.P.D. of D.G.M.A.M.C. \& Hospital Gadag, and medical camps were conducted after fulfilling the inclusion and exclusion criteria.

\section{Inclusion Criteria:}

1. Panduta in Twak, Nakha, Netra, Jihwa, Hasthapadatala (pallor in nails, conjunctiva, tongue, palm and sole), Shrama (fatigue), Brama (giddiness), Dourbalya (weakness), Arohanaayasa (exertional dysponea), Aruchi (anorexia), Pindakodwestana (muscle cramps) and Gatrashoola (body ache).

2. Patients of Panduroga between the age group of $10-60$ years.

3. $\mathrm{Hb} \%$ between $6 \mathrm{gm} / \mathrm{dl}-10 \mathrm{gm} / \mathrm{dl}$.

\section{Exclusion Criteria:}

1. Known cases of Thalassemia, Sickle Cell Anemia, Pernicious Anemia.

2. Anemia associated with any malignancy.

3. Patients under chemotherapy and radiation treatment etc.

4. Patients suffering from DM and HTN.

5. Anemia due to hookworm infestation.

\section{Selection of drug:}

Background of drug selection: With the reference of Rasendra Sara Sangraha SammohaLoha ${ }^{5}$ was chosen for the study. This is indicated in Panduroga and it contains drugs like Pippali, Maricha, Shunti, Chitraka, Amalaki, Vibhitaki, Hritaki, Vidanga, Lohabhasma, Abhrakabhasma and Ghrita. This has properties like Balaya, Varnaya, Agnivardhana, Kamala, Pandurogahara, Hridroga, Shotahara, Krimighna, hence the drug was chosen for the trial. Ferrous Sulphate was taken as a standard drug for comparison.

Table 1: Ingredients, parts used and proportion of trail drug

\begin{tabular}{|l|l|l|l|l|}
\hline SL.NO & DRUG & BOTANICAL NAME & PART USED & PROPORTION \\
\hline 1 & Pippali & Piper longum & Fruit & 1 part \\
\hline 2 & Marica & Piper nigrum & Fruit & 1 part \\
\hline 3 & Sunthi & Zingiber Officinalis & Rhizome & 1 part \\
\hline 4 & Amalaki & Embelica officinalis & Fruit pulp & 1 part \\
\hline
\end{tabular}




\begin{tabular}{|l|l|l|l|l|}
\hline 5 & Vibhitaki & Terminalia belerica & Fruit pulp & 1 part \\
\hline 6 & Haritaki & Terminalia chebula & Fruit pulp & 1 part \\
\hline 7 & Vahni & Plumbago zeyalanica & Root & 1 part \\
\hline 8 & Vidanga & Embilicaribes & Fruit & 1 part \\
\hline 9 & Loha & Iron & Incinerated iron & 1 part \\
\hline 10 & Abhraka & Biotite & Incinerated mica & 1 part \\
\hline 11 & Ghrita & Ghee & Ghee & q.s \\
\hline
\end{tabular}

Schedule of treatment: cases registered for the study were randomly grouped into two.

Group A- the patient was treated with a trial drug i.e. SammohaLoha, 250mg TID

Group B- the patient was treated with standard drug i.e. Ferrous Sulphate, $150 \mathrm{mg}$ TID

Form of drug - trial drug in the form of a capsule, standard drug in the form of a tablet.

Time - after food

Duration - 30days

The patient was assessed on the $0^{\text {th }}, 15^{\text {th }}, 30^{\text {th }}, 45^{\text {th }}$ and $60^{\text {th }}$ days.

Follow up - 30 days

Total study duration -60 days

Approval of institutional ethical committee: Institutional ethical committee's approval has been taken for this comparative, randomized study.

Subjective Parameters: Panduta in Twak, Nakha, Netra, Jihwa, Hasthapadatala, Shrama, Brama,
Dourbalya, Arohanaayasa, Aruchi, Pindakodwestana and Gatrashoola.

Objective Parameters: In this study CBC (red cell indices i.e. Haemoglobin levels, RBC, PCV/HCT, $\mathrm{MCV}, \mathrm{MCH}, \mathrm{MCHC}$ ) and Serum Ferritin were the objective parameters undertaken.

\section{Laboratory investigations:}

- Complete blood count (CBC)

- RBS

- Serum Ferritin

- Stool examination (if necessary)

- Urine routine

Criteria for Assessment: assessment was done by considering the baseline of data, subjective and objective parameters to pre and post medication. All the results were analyzed statistically using the unpaired 't'-test.

Table 2: Grading of subjective parameters

\begin{tabular}{|l|l|l|l|l|}
\hline Grades & Panduta & Shrama & Bhrama & Arohanaayasa \\
\hline $\mathbf{0}$ & Absent & Absent except hard work & Absent & Absent after climbing the stairs \\
\hline $\mathbf{1}$ & In any 2 of them & After moderate work for a certain time & Occasionally present & Exertion after climbing the stairs \\
\hline $\mathbf{2}$ & $\begin{array}{l}\text { In any } 3 \text { of these } \\
\text { In any } 4 \text { and } \\
\text { more }\end{array}$ & $\begin{array}{l}\text { After little work for a certain time } \\
\text { After routine activities for a certain }\end{array}$ & $\begin{array}{l}\text { Persistent throughout the } \\
\text { year }\end{array}$ & Unable to climb stairs \\
\hline
\end{tabular}

\begin{tabular}{|c|c|c|c|c|}
\hline Grades & Dourbalya & Aruchi & Pindakodwestana & Gatrashoola \\
\hline $\mathbf{0}$ & $\begin{array}{l}\text { No feeling of Dourbalya during } \\
\text { daily activities }\end{array}$ & Normal desire to take food & Absent & $\begin{array}{l}\text { Absent except hard } \\
\text { work }\end{array}$ \\
\hline 1 & Sometimes felt but performs work & Most of the tines dislikes food & Occasionally present & After moderate work \\
\hline 2 & $\begin{array}{l}\text { Often the feeling of Dourbalya } \\
\text { hampers daily activities }\end{array}$ & $\begin{array}{l}\text { Dislikes food even though } \\
\text { hungry but takes food }\end{array}$ & Frequently present & After light work \\
\hline 3 & $\begin{array}{l}\text { Always feeling of Dourbalya, } \\
\text { unable to perform daily activities }\end{array}$ & $\begin{array}{l}\text { Dislikes the food and takes a } \\
\text { little or doesn't take food }\end{array}$ & $\begin{array}{l}\text { Persistent (throughout the } \\
\text { day) }\end{array}$ & $\begin{array}{l}\text { After routine activities, } \\
\text { needs medication }\end{array}$ \\
\hline
\end{tabular}

Objective Criteria Assessment: The following laboratory assessment was assessed pre and post-treatment $\mathrm{Hb} \%, \mathrm{PCV}, \mathrm{RBC}, \mathrm{MCV}, \mathrm{MCH}, \mathrm{MCHC}$ and Serum Ferritin. 


\section{Observations and Results:}

Table 3: Statistical analysis

\begin{tabular}{|c|c|c|c|c|c|c|c|c|}
\hline & Group A & & & & Group B & & & \\
\hline Parameters & Mean BT & Mean AT & $\%$ relief & P-value & Mean BT & Mean AT & $\%$ relief & P-value \\
\hline Panduta & 2.1 & 0.65 & $60.97 \%$ & $<0.0001$ & 2.45 & 0.4 & $85.83 \%$ & $<0.0001$ \\
\hline Dourbalya & 1.5 & 1.5 & $92.5 \%$ & $<0.0001$ & 1.8 & 0.1 & $95 \%$ & $<0.0001$ \\
\hline Shrama & 1.4 & 0.3 & $74.16 \%$ & $<0.0001$ & 1.25 & 0 & $85 \%$ & $<0.0001$ \\
\hline Bharama & 0.8 & 0.5 & $62.5 \%$ & $<0.0001$ & 0.7 & 0 & $60 \%$ & $<0.0001$ \\
\hline Pindakodwestana & 1.1 & 0 & $85 \%$ & $<0.0001$ & 0.05 & 0.95 & $87.5 \%$ & $<0.0001$ \\
\hline Arohanaayasa & 1.6 & 0.1 & $95 \%$ & $<0.0001$ & 1.75 & 0.05 & $97.5 \%$ & $<0.0001$ \\
\hline Aruchi & 1.2 & 0 & $80 \%$ & $<0.0001$ & 0.6 & 0 & $90 \%$ & 0.0004 \\
\hline Gatrashoola & 0.95 & 0.05 & $82.5 \%$ & $<0.0001$ & 0.0 & 0.66 & $55 \%$ & 0.0001 \\
\hline Shirashoola & 0.65 & 0 & $95 \%$ & $<0.0001$ & 0.35 & 0.05 & $30 \%$ & 0.01 \\
\hline $\mathrm{Hb}$ & 9.12 & 9.67 & $5.36 \%$ & 0.0002 & 8.85 & 10.87 & $18.76 \%$ & $<0.0001$ \\
\hline $\mathrm{Rbc}$ & 4.31 & 4.24 & $-0.48 \%$ & 0.33 & 4.13 & 4.35 & $5.07 \%$ & 0.01 \\
\hline PCV & 28.79 & 28.7 & $1.63 \%$ & 0.97 & 28.33 & 32.93 & $13.25 \%$ & 0.0005 \\
\hline $\mathrm{MCV}$ & 64.8 & 68.24 & $4.45 \%$ & 0.012 & 65.1 & 74.75 & $16.8 \%$ & $<0.0001$ \\
\hline $\mathrm{MCH}$ & 21.35 & 22.59 & $9.57 \%$ & 0.001 & 21.05 & 25.96 & $18.32 \%$ & $<0.0001$ \\
\hline $\mathrm{MCHC}$ & 21.35 & 22.59 & $1.08 \%$ & 0.001 & 31.7 & 32.9 & $2.45 \%$ & 0.25 \\
\hline Sr. Ferritin & 3.58 & 4.29 & $10.46 \%$ & 0.06 & 6.29 & 29.31 & $86.36 \%$ & $<0.0001$ \\
\hline
\end{tabular}

Table 4: Showing the comparative efficacy of the therapies in Group A and Group B by using unpaired ' $t$ ' test

\begin{tabular}{|c|c|c|c|c|c|c|c|c|c|c|c|}
\hline \multirow[t]{2}{*}{ Sl.No. } & \multirow[t]{2}{*}{ Parameters of Assessment } & \multirow[t]{2}{*}{ Noof Pts } & \multicolumn{3}{|c|}{ Group A } & \multicolumn{3}{|c|}{ Group B } & \multirow[t]{2}{*}{$\mathbf{T}$ value } & \multirow[t]{2}{*}{ P-value } & \multirow[t]{2}{*}{ Remark } \\
\hline & & & Mean & SD & SE & Mean & SD & SE & & & \\
\hline 1 & Panduta & 40 & 1.45 & 0.60 & 0.13 & 2.05 & 0.68 & 0.15 & -2.93 & 0.005 & $\mathrm{~S}$ \\
\hline 2 & Dourbalya & 40 & 1.35 & 0.58 & 0.13 & 1.7 & 0.47 & 0.10 & -2.08 & 0.04 & $\mathrm{~S}$ \\
\hline 3 & Shrama & 40 & 1.1 & 0.64 & 0.14 & 1.25 & 0.78 & 0.17 & -0.66 & 0.51 & N.S \\
\hline 4 & Brama & 40 & 0.75 & 0.63 & 0.14 & 0 & 0.65 & 0.14 & 0.24 & 0.80 & N.S \\
\hline 5 & Pindakodvestana & 40 & 1.1 & 0.64 & 0.14 & 0.95 & 0.39 & 0.08 & 0.89 & 0.3 & N.S \\
\hline 6 & Arohanaayasa & 40 & 1.5 & 0.60 & 0.13 & 1.7 & 0.47 & 0.10 & -1.16 & 0.25 & N.S \\
\hline 7 & Aruchi & 40 & 1.2 & 0.83 & 0.18 & 0.6 & 0.82 & 0.18 & 2.29 & 0.02 & $\mathrm{~S}$ \\
\hline 8 & Gatrashoola & 40 & 0.9 & 0.44 & 0.1 & 0.43 & 0.65 & 0.14 & 1.33 & 0.19 & N.S \\
\hline 9 & Shirashoola & 40 & 0.65 & 0.48 & 0.10 & 0.3 & 0.47 & 0.10 & 2.30 & 0.02 & S \\
\hline 10 & $\mathrm{Hb} \%$ & 40 & -0.55 & 0.54 & 0.12 & -2.02 & 0.67 & 0.15 & 7.50 & $<0.0001$ & H.S \\
\hline 11 & $\mathrm{PCV} / \mathrm{HCT}$ & 40 & 0.03 & 4.21 & 0.94 & -4.6 & 4.94 & 1.10 & 3.18 & 0.002 & $S$ \\
\hline 12 & $\mathrm{RBC}$ & 40 & 0.06 & 0.30 & 0.06 & -0.22 & 0.36 & 0.08 & 2.76 & 0.008 & $\mathrm{~S}$ \\
\hline 13 & $\mathrm{MCV}$ & 40 & -3.36 & 5.48 & 1.22 & -9.65 & 7.13 & 1.59 & 3.12 & 0.003 & $S$ \\
\hline 14 & $\mathrm{MCH}$ & 40 & -1.24 & 1.44 & 0.32 & -4.93 & 3.91 & 0.87 & 3.95 & 0.0005 & H.S \\
\hline 15 & $\mathrm{MCHC}$ & 40 & -1.24 & 1.44 & 0.32 & -1.17 & 4.50 & 1 & -0.061 & 0.95 & N.S \\
\hline 16 & Sr.Ferritin & 40 & -0.70 & 1.58 & 0.35 & -23.01 & 8.47 & 1.89 & 11.56 & $<0.0001$ & H.S \\
\hline
\end{tabular}

\section{Group A}

Markedly improved - 4(20\%)

Moderate improvement $-10(50 \%)$

Mild improvement - 3(15\%)

Unchanged - 3(15\%)

\section{DISCUSSION}

Panduroga is Varnoplakshitavyadhi (disease of discolouration) where Panduta looks like Ketakidula

\section{Group B}

Cured - 7(35\%)

Markedly improved $-8(40 \%)$

Moderate improvement - 3(15\%)

Unchanged - 2(10\%)

mixture of white and yellow colour like pollen grains of Ketaki flower. Acharya Charaka tells Pandu as Rasapradoshaja vyadhi ${ }^{7}$, Acharya Sushruta tells it as 
Raktapradoshajavyadhi and here we must consider nutritional deficiency as Rasapradoshaja and lack of blood as Raktapradoshaja.

In this study $27(67.5 \%)$ of the patients belonged to the 20-30 age group, $6(15 \%)$ patients belonged to the $40-50$ age group, $5(12.5 \%)$ patients belonged to the $30-40$ age group and $1(2.5 \%)$ patient belonged to 10 20 and 50-60age group each. This shows that all the age group people get affected by Panduroga.

The study shows $34(85 \%)$ patients were middle class, $3(7.5 \%)$ were rich and $3(7.5 \%)$ were poor of socioeconomic background. This shows all of them need to be educated about the disease.

The study showed 20(50\%) of patients belonged to the Vatapitta type of Shariraparkruti, $18(45 \%)$ patients belonged to Pittakaphaja and 2(5\%) patients belonged to Vatakaphaja prakruti. This shows Vatapitta are more prone to Pittajavyadhi followed by Pittakaphaja prakruti persons.

In this study, all of the 40(100\%) patients had Panduta, Dourbalya and Arohanaayasa. Panduroga itself tells Pandu Varna as cardinal feature. Dourbalya due to malnourishment of Dhatus leads to Dhatukshaya (depletion of tissues) which leads to debility. Arohanaayasa be due to less amount of blood leads to less oxygen supply to the body tissues, hence body demands more oxygen causing exertional dysponea.

In this study, 35 (87.5\%) of the subjects had Shrama, which may be due to Dhatukshaya, Raktaalpata (less amount of blood), as well as Ojakshaya (suppression of immunity) and 25 (62.5\%) of the subjects, had Bhrama, may be due to Rasakshaya. In this study 25 (62.5\%) of the patients had Aruchi. In Panduroga, there is Dravarupa pitta vruddhi, which leads to mandagni (decreased Agni) then the formation of Ama (undigested food particle), due to Ama there will be Aruchi.

In this study $34(85 \%)$ of the subjects had Pindakodvestana. This may be due to Dhatukshaya which leads to Vatavruddhi causes Pindakodvestana. In this study 26 (65\%) of the patients had Gatrashoola. This may be due to Vatavruddhi and $22(55 \%)$ of the patients had Shirashoola, which may be due to lack of blood supply and oxygen supply to the body tissues.
SammohaLoha contains drugs like Pipali, Maricha, Shunti, Chitraka, Amalaki, Vibitaki, Haritaki, Vidanga, Lohabhasma, Abrakabhasma. This has properties like Balaya, Varnaya, Agnivardhaka, Pandu, Kamala Rogahara, Shotahara, Hridrogahara, Krimighana, hence the drug is chosen for the trail. Trial medicine was prepared according to the classical reference.

In this yoga Trikatu i.e. Pipali, Maricha, Shunti, these are the Ushna dravyas which does Amapachana, Agnideepana, removes Ama, Aruchi and gives Ruchikara.

Tripahala i.e. Amalaki, Vibhitaka, Haritaki these are Tridoshaghana. Haritaki initiates Anulomana (regulation) effect and prevents the probable chances of constipation resulted due to Loha and Abhrakabhasma. Amalaki is a rich source of natural vitamin $\mathrm{C}$ which helps in the better absorption of iron. Vibhitaki has Ushnaveerya (hot potency) which does Amapachana(digests the Ama).

Vidanga the main karma is Krimighana (antihelminthic), as hookworm infestation is one of the causes for Panduroga it acts on Krimi(worm). Chitraka and Vidanga both are Ushana dravyas so does Amapachana and Srotoshodhana. Lohabhasma and $A b$ hrakabhasma are the main iron contents in the drug, and they are Ruchya, Ayushya, Balya, Rasayana etc. Here the herbal ingredient corrects the metabolism and enhances the bioavailability of nutrients to the body.

Ferrous Sulphate is a Standard drug that was chosen for comparative study. Ferrous Sulphate is directly indicated in Iron Deficiency Anaemia, so it is chosen as a standard drug for comparison, and this was bought from the registered pharmacy.

Discussion on subjective parameters: Pallor, weakness, fatigue, giddiness, exertional dysponea, muscle cramps, anorexia, body ache and headache have been relived after treatment in a complaint to before treatment is $60.97 \%, 92.5 \%, 74.16 \%, 62.5 \%, 95 \%, 85 \%$, $80 \%, 82.5 \%$ and $65 \%$ respectively where the p-value for all the above parameters is $<0.0001$ which is highly significant with SammohaLoha. 
Discussion on objective parameters: $\mathrm{Hb} \%, \mathrm{RBC}$, PCV, MCV, MCH, MCHC and Serum Ferritin are the objective parameters, and their relief factor is $5.36 \%,-0.48 \%, 1.63 \%, 4.45 \%, 9.57 \%, 1.08 \%$ and $10.46 \%$ respectively and $\mathrm{p}$ values is 0.00002 (highly significant), 0.33 (not significant), 0.97 (not significant), 0.012 (significant), 0.001(significant), 0.001 (significant) and 0.06 (not significant) these were the statistical analysis noted in the trail group.

SammohaLoha has given highly significant results in subjective parameters, which shows that it corrects the basic pathophysiology. All the ingredients are in a combination of Ushnaveerya, Deepana, Pachana action which clears the undigested food particles and clears the channels, then helps in better absorption of nutrients to the body.

Patients under the Ferrous Sulphate group had highly significant results in both subjective and objective parameters. Among 20 patients 5 of them had side effects, two of them had constipation, two of them had nausea and one had epigastric discomfort. These were the common side effects of this drug which were noted during the ferrous sulphate medication intake.

\section{CONCLUSION}

Without a conclusion always a study is incomplete. Panduroga is one of the leading nutritional deficiencies in the world affecting all the age groups of people, mainly females than males.

Group A was given trial drug SammohaLoha and Group B was given standard drug Ferrous Sulphate. Among them, Group A has shown highly significant results in subjective parameters and Group B has shown highly significant results in both subjective and objective parameters.

\section{REFERENCES}

1. Jameson, Fauci, Kasper, Hausser, Longo, Loscalzo, Harrison's principle of internal medicine, volume 1, Chapter no. 59, $20^{\text {th }}$ edition 2018, published by MC Graw hill education, page no. 385 .

2. https://onlinelibrary.wiley.com/doi/full/10.1111/joim. 13004
3. KD Tripathi, Essential Medical pharmacology, Chapter 43 , Section $10,6^{\text {th }}$ edition 2010 , Jaypee Publications, page no. 585.

4. http://www.randomization.com/http://www.jerrydallal.com/random/randomize.htm

5. Sri Gopal Krishna Bhatt, Rasendra Sara Sangraha, treatment of Pandu and Kamala Chikitsa, chapter no. 2, shloka no. 47-49, edition $1^{\text {st }}$ 2007, Chaukamba Sanskrit SansthanVarnasi, page no. 453-454.

6. Vachaspatyam, $5^{\text {th }}$ volume, Shritaranath, Chaukambha Sanskrit series office, Varanasi, reprint edition 2002, page no. 4294.

7. Agnivesha, Charaka Samhita, Acharya VidyadharShulka, Prof. Ravi Datt Tripathi, Sutra Sthana, Chapter no. 28, shloka no. 10, reprinted 2017, Chaukamba Sanskrit Pratishthana. Page no. 429.

\section{Source of Support: Nil \\ Conflict of Interest: None Declared}

How to cite this URL: Rajeshwari M S \& R V Shettar: A Standard Comparative Clinical Study On Panduroga W.S.R To Iron Defi-Ciency Anaemia With Sammoha Loha Over Ferrous Sulphate. International Ayurvedic Medical Journal \{online\} 2021 \{cited September 2021\} Available from: http://www.iamj.in/posts/images/upload/3090 3095.pdf 